\title{
Conflict Resolution and the Everyday Politics of International Intervention
}

\author{
Christian VÖLKEL*
}

\section{Conflict Resolution and the Everyday Politics of International Intervention}

Severine Autesserre

Cambridge University Press

The behavior of international peace builders is full of oddities and contradictions. They are often as concerned about their security as about that of the countries in which they intervene. They are deployed to help communities, yet they often lack contact with locals and instead spend much of their working day on compiling reports for headquarters and donors. And despite an acknowledgment that local needs and preferences matter, peace-building projects regularly are carbon copies of standard models imported from the outside. But does the interveners' behavior have an impact on their effectiveness? That is the question Séverine Autesserre sets out to answer in her thoughtful book Peaceland. Conflict Resolution and the Everyday Politics of International Intervention. Despite drawing heavily on field work in African contexts, her findings and recommendations are nonetheless relevant for Colombia's quest of peace.

\section{$* * *$}

* Investigador independiente. Correo electrónico: cvoelkel1@gmail.com 
At the heart of the book lies an argument of how patterns of routine behavior shape, condition and partially undermine the most-well intended efforts of international peace builders, including military forces, multilateral institutions such as the UN and a growing crowd of non-governmental organizations. This builds on the observation that peace-builders in the field do not just execute orders from headquarters, but that their actions have an independent effect on ending conflict. Interveners in fact enjoy significant autonomy in adjusting broad mandates to local realities, and their actions shape the attitudes of local communities towards international intervention.

To analyze the on-the-ground behavior of peacebuilders, Auteresse distinguishes between practices, habits and narratives. Practices are regular patterns of "doing something" that are interpreted by groups of individuals in a similar manner. Typical practices of peacebuilders include holding coordination meetings or striving to remain impartial. Habits, such as socializing primarily with other expatriates or following strict security procedures, are similar to practices, but they are more unconscious and "automatic" responses to the world. Finally, narratives are stories that interveners use to interpret and make sense of their environments. For instance, peacebuilders commonly attribute violence in their host countries to a single cause that often suggests clear-cut solutions.

Autessere uses an ethnographic approach to study these "everyday" aspects of international interventions. Most of the empirical material stems from a year-long stay in Eastern Congo. Complementary fieldwork in eight other conflict zones with vastly different characteristics, including Israel and the Palestinian Territories, Cyprus and South Sudan, provides additional insights and allows for some cautious generalization of the findings.

One strength of the book lies in its nuanced assessments. The "everyday politics" of intervention have a variety of partially contradictory effects. For instance, strict security procedures, such as 
avoiding movements after night fall, travelling in convoys or living in guarded compounds, allow interveners to operate in hostile and often dangerous zones where peacebuilders increasingly risk becoming targets of violence themselves. But the same "bunkerization" routines also have unintended, counterproductive consequences. They underscore the existing segregation and separation of interveners from their host communities, making it even harder for locals to interact with the internationals. This, in turn, reinforces a tendency among peacebuilders to relate mostly to their peers. Onerous and time-consuming security procedures can also mean that interveners cannot react quickly to emergency situations in the field. The sideeffects of such seemingly sensible routines make promoting sustainable peace much harder to achieve.

The ambiguity inherent in the practices that underpin the operations of international peaceworkers is perhaps most clearly visible in a fascinating analysis of how well-meaning discourses on the causes of and solutions to conflict can end up perpetuating violence. According to widely held beliefs, violence in Congo was mainly driven by the illegal exploitation of so-called conflict minerals, such as gold, diamonds and others, and that this violence had its worst expression in rampant sexual violence, in particular rape. To overcome these problems, the dominant discourse held that state authority needed to be reconstructed.

These elements framed the perception of the conflict in Congo and they shaped the international response to it. This discourse helped improve care and protection for victims of sexual violence-undoubtedly an important achievement. But it also obscured the relevance of the root causes of violence, for instance local conflicts over land or the exercise of political authority. It also reportedly distorted the provision of health services to a point that sometimes women had to claim they were raped to obtain access to care; some illegal armed group also came to see sexual violence as a tool and a strategy to draw international attention to their grievances. 
Everyday routines help a highly diverse group of individuals create a sense of belonging to the broader community of peacebuilders. This is part of the reason why they tend to be self-reinforcing. The heroes of the book are individuals and organizations that call into question the dominant paradigms, sometimes at considerable costs for their careers and reputation. Faith-based organizations, newcomers to "peaceland" and interveners with deep personal links to specific local communities are often more open to challenging standard practices. As Auresserre shows, these individuals and organization can avoid some of the pitfalls that haunt mainstream intervention. They often have access to better information and thus command a more nuanced understanding of local cleavages and conflicts; they take local input more seriously, and they are more trusted by host communities, all of which facilitates ending violence.

The experiences analyzed in Autesserre's book have at first sight little bearing on Colombia. Despite significant involvement of the international community, national actors are by and large in the driver's seat when it comes to peace-building. Reflecting a broad pool of qualified professionals, Colombians are in important leadership positions in both multilateral organizations and international NGOs. The cultural gap between the expatriates and nationals is also arguably narrower than in many African and Asian countries, thus reducing problems of separation and segregation. And not least, Colombia's current peace process with the FARC explicitly calls for formal negotiations to be followed by a bottom-up (rather than top-down) effort of constructing peace.

Yet the country is no stranger to some of the dynamics that are characteristic of "peaceland." Interventions regularly have a short time span, and their success is often being measured by easily quantifiable indicators which tend to miss more important aspects of peace-building, such as changes in attitudes towards the use of violence as a means of conflict resolution. And despite Colombia's long experience with grass-roots peace-building, state policies are often centrally 
planned and struggle to adjust to local circumstances. The pitfalls of peace-building described by Autesserre are not an exclusive problem of internationally-driven interventions; national policies might be just as vulnerable to them.

$$
* * *
$$

Taken together, Peaceland is an important book. It builds on rich fieldwork and a bulk of literature on international interventions in developing countries to advance a novel and sophisticated argument about the potential and the limitations of efforts to promote peace or prevent the recurrence of violence. 
